\title{
Effect of Service Quality, Satisfaction and Awareness on Taxpayer Compliance with Financial Conditions as Moderating Variables at the Tax Service Office (KPP) Pratama Deli Serdang
}

\author{
Evita Sari Sinaga ${ }^{1}$, Endang Sulistya Rini ${ }^{2}$, Beby Karina Fawzeea Sembiring ${ }^{2}$ \\ ${ }^{1}$ Postgraduate Students, Department of Management, Faculty of Economics and Business at Universitas \\ Sumatera Utara, Indonesia \\ ${ }^{2}$ Postgraduate Lecturer, Department of Management, Faculty of Economics and Business at Universitas \\ Sumatera Utara, Indonesia \\ Corresponding Author: Evita Sari Sinaga
}

\begin{abstract}
The self-assessment system that applies in Indonesia gives full confidence to taxpayers to calculate, calculate, pay, and self-report the amount of tax owed, while the tax authorities are only tasked with providing services, supervision, and guidance to taxpayers. In essence, the taxpayer knows more about how much income is earned, so the amount of tax that must be paid can be calculated by the taxpayer himself. The purpose of this study was to determine and analyze the effect of service quality, satisfaction and awareness on taxpayer compliance with financial conditions as moderating variables at the tax service office (KPP) Pratama Deli Serdang. The data used are primary data obtained directly from respondents, amounting to 300 people. This study uses the moderated regression analyze (MRA) method with the help of the SPSS program. The results showed that service quality, satisfaction and awareness partially had a positive and significant effect on taxpayer compliance. Financial conditions have a negative and significant effect on taxpayer compliance. Financial conditions moderates the effect of satisfaction on service quality is negative and significant. Financial conditions moderating the effect of satisfaction on taxpayer compliance is negative and significant. Financial condition moderates the effect of awareness on taxpayer compliance is positive and significant.
\end{abstract}

Keywords: Service Quality, Satisfaction, Awareness, Taxpayer Compliance, Financial Conditions

\section{INTRODUCTION}

To finance government development programs, both physical and non-physical sectors, funding sources are needed from the state revenue and expenditure budget (APBN). State expenditures or expenditures include central government expenditures and regional government expenditures. Central government expenditures consist of routine expenditures and development expenditures. While the source of state revenue consists of domestic revenue and grants. Domestic revenues consist of tax revenues basically consist of domestic tax revenues and foreign tax revenues. Domestic tax revenues consist of PPh, PPN, and PPnBM, customs, PBB, and other taxes, while foreign taxes consist of import duties and export taxes.

In the structure of state revenue, tax revenue has a very strategic role and is the main source of domestic revenue to support the financing of government administration and national development. Tax revenues have made a very significant contribution in providing sources of funds for financing various programs to overcome the economic crisis. The government through the Ministry 
of Finance which oversees the Directorate General of Taxes continues to strive so that the tax revenue plan that has been determined every year can continue to be achieved. Laws and regulations related to taxation continue to be refined so that taxes can be more accepted by the public.

The self-assessment system that applies in Indonesia gives full confidence to taxpayers to calculate, calculate, pay, and self-report the amount of tax owed, while the tax authorities are only tasked with providing services, supervision, and guidance to taxpayers. In essence, the taxpayer knows more about how much income is earned, so the amount of tax that must be paid can be calculated by the taxpayer himself.

According to Widodo (2014), "Service quality is every effort made by the organization (bureaucracy) of producers of goods or sellers of services that is shown to customers by providing optimal satisfaction". Service quality has a positive and significant effect on taxpayer compliance (Syahputra, 2015 and Utama, 2011). The results of this study indicate that service quality is a determinant of whether or not taxpayers comply in paying taxes, in addition to other variables.

According to Rangkuti (2012), "Customer satisfaction is a person's feeling of pleasure or disappointment as a result of a comparison between perceived and expected achievements or products". Taxpayer satisfaction has a positive and significant effect on taxpayer compliance (Utama, 2011). The results of this study indicate that taxpayer satisfaction is a determinant of whether or not taxpayers comply in making tax payments, in addition to other variables.

According to Kurniawan (2010), "Awareness is the level of individual alertness at this time to external and internal stimuli, meaning to environmental events and body sensations, memories and thoughts". Taxpayer awareness has a positive and significant effect on taxpayer compliance (Hamdani, 2013 and Syahputra et al, 2011). The results of this study indicate that the awareness of taxpayers is a determinant of whether or not taxpayers comply in paying taxes, in addition to other variables.

The financial condition of the taxpayer is the level of satisfaction of the taxpayer with the financial condition of the taxpayer himself and his family (Julianti, 2014). The financial condition of the taxpayer can moderate other variables, namely service quality, taxpayer satisfaction, and taxpayer awareness of taxpayer compliance (Yasa and Jati, 2015 and Yudi, 2011). The results of this study indicate that financial conditions can moderate whether or not taxpayers comply in making tax payments, in addition to other variables.

A good taxpayer's financial condition has an impact on the level of taxpayer compliance which tends to increase and vice versa, if the taxpayer's financial condition is low, the level of taxpayer compliance tends to decrease.

Public services are increasingly important to get serious attention because of the reality that people often complain and feel dissatisfied with various services provided by government agencies. Based on this, it is necessary to make improvements to the service system that has been carried out so that in future implementation it can be more effective and efficient in providing services. In order to meet these demands, the readiness and ability of the government apparatus needs to be improved so that the goal of providing maximum service can be achieved. Taxpayer satisfaction is the main thing in service delivery because the service that has been provided is a determinant of whether or not the taxpayer is satisfied, for that at agencies such as the Deli Serdang Tax Service Office, the quality of service is very important to manage because one of the factors that affect taxpayer satisfaction is service quality. With good service quality, of course, the public, especially taxpayers, will feel satisfied and by itself will increase 
public awareness in fulfilling their rights and obligations in terms of taxation.

The purpose of this study was to determine and analyze the effect of service quality, satisfaction and awareness on taxpayer compliance with financial conditions as moderating variables at the tax service office (KPP) Pratama Deli Serdang.

\section{RESEARCH METHODS}

This study was conducted to test the proposed hypothesis using research methods that have been designed in accordance with the variables to be studied in order to obtain accurate results. This type of research is quantitative. According to Sinulingga (2014) that quantitative research is a type of research that aims to describe systematically, factually and accurately about the facts and characteristics of a particular object or population. This study aims to determine and analyze the influence of marketing mix factors that affect repurchase interest through customer satisfaction. This research is carried out through data collection and quantitative analysis (questionnaires) and testing using path analysis.

The nature of this research is research that explains the causal relationship between variables through hypothesis testing. This is in accordance with the research objective, namely to explain the causal relationship that occurs between exogenous variables and endogenous variables by testing hypotheses.

The data used are primary data obtained directly from respondents, amounting to 300 people.

This study uses the moderated regression analyze (MRA) method with the help of the SPSS program.

\section{RESULT \\ KPP Pratama Deli Serdang \\ Vision}

Become a community service model. Reflects the aspiration to be an example of community service for other government agencies. World class. Reflecting the aspiration to achieve the level of world standards or international standards both for the quality of the apparatus as well as the quality of performance and results.

Trusted and proud of the community. Reflects the aspiration to get recognition from the public that its existence and performance are truly of high quality and accurate, capable of meeting people's expectations and having a good and clean image.

\section{Mission}

Collect domestic funds from the tax sectors that are able to support the independence of government financing based on tax laws with a high level of effectiveness and efficiency.

\section{Descriptive Statistical Data Analysis}

Respondents in this study were 300 taxpayers at KPP Pratama Deli Serdang. Characteristics of respondents are described based on age, gender, education level, position, length of work, and marital status.

Based on the data, it can be seen that 36 respondents $(46 \%)$, male respondents and 36 female respondents (54\%).

Based on the data, it can be seen that there are 8 respondents aged between 22 and 26 years $(12 \%), 5$ respondents aged between 27 and 31 years (8\%), 10 respondents aged between 32 and 36 years (15\%), respondents aged between 37 years to 41 years as many as 4 people (6\%), respondents aged 42 years to 46 years as many as 8 people (12\%), respondents aged 47 to 51 years as many as 13 people ( $19 \%$ ), respondents aged 52 to 57 years were 19 people (28\%).

Based on the data, it can be seen that the respondents with the last education of high school are 8 people (12\%), respondents with the last education D3 (Diploma III) as many as 6 people $(9 \%)$, respondents with the last education S1 (Strata I) as many as 43 people $(64 \%)$, and 10 respondents with the latest Master's degree education (10\%).

Based on the data, it can be seen that the respondents who have worked for 2 
years to 6 years are 8 people (12.\%), respondents who have worked for 7 years to 11 years are 24 people $(36 \%)$, respondents who have worked for 12 years to 11 years. 16 years as many as 4 people (6\%), respondents who have worked for 17 years to 21 years as many as 2 people (3\%), respondents who have worked for 22 years to 26 years as many as 10 people $(15 \%)$, respondents who have worked for 27 years to 31 years as many as 12 people $(18 \%)$, respondents who have worked for 32 years to 33 years are 10 people $(10 \%)$.

\section{Moderated Regression Analyze (MRA) Test Results Substructure Equation 1}

Table 1. Substructure Equation 1

Coefficients $^{\mathbf{a}}$

\begin{tabular}{|c|c|c|c|c|c|c|c|c|}
\hline \multirow{2}{*}{\multicolumn{2}{|c|}{ Model }} & \multicolumn{2}{|c|}{ Unstandardized Coefficients } & \multirow{2}{*}{$\begin{array}{l}\text { Standardized Coefficients } \\
\text { Beta }\end{array}$} & \multirow[t]{2}{*}{$\mathbf{t}$} & \multirow[t]{2}{*}{ Sig. } & \multicolumn{2}{|c|}{ Collinearity Statistics } \\
\hline & & $\mathbf{B}$ & Std. Error & & & & Tolerance & VIF \\
\hline \multirow[t]{4}{*}{1} & (Constant) & -1.303 & 1.177 & & -1.107 & .269 & & \\
\hline & Service Quality & .071 & .022 & .150 & 3.197 & .002 & .801 & 1.249 \\
\hline & Satisfaction & .152 & .041 & .174 & 3.701 & .000 & .804 & 1.244 \\
\hline & Awareness & .829 & .066 & .556 & 12.563 & .000 & .904 & 1.106 \\
\hline
\end{tabular}

a. Dependent Variable: Taxpayer Compliance

\section{Substructure Equation 2}

Table 2. Substructure Equation 2

Coefficients $^{\mathrm{a}}$

\begin{tabular}{|c|c|c|c|c|c|c|}
\hline \multirow{2}{*}{\multicolumn{2}{|c|}{ Model }} & \multicolumn{2}{|c|}{ Unstandardized Coefficients } & \multirow{2}{*}{$\begin{array}{l}\text { Standardized Coefficients } \\
\text { Beta } \\
\end{array}$} & \multirow[t]{2}{*}{$\mathbf{t}$} & \multirow[t]{2}{*}{ Sig. } \\
\hline & & $\mathbf{B}$ & Std. Error & & & \\
\hline \multirow[t]{8}{*}{1} & (Constant) & 5.073 & 1.298 & & 3.909 & .000 \\
\hline & Service Quality & .109 & .026 & .230 & 4.135 & .000 \\
\hline & Satisfaction & .129 & .042 & .150 & 3.090 & .002 \\
\hline & Awareness & .005 & .018 & .004 & .274 & .784 \\
\hline & Financial Conditions & -.537 & .171 & -.293 & -3.146 & .002 \\
\hline & Service Quality. Financial Conditions & -.014 & .004 & -.523 & -3.958 & .000 \\
\hline & Satisfaction. Financial Conditions & -.019 & .006 & -.307 & -3.426 & .001 \\
\hline & Awareness. Financial Conditions & .121 & .002 & 1.783 & 49.735 & .000 \\
\hline
\end{tabular}

a. Dependent Variable: Taxpayer Compliance

The results showed that service quality, satisfaction and awareness partially had a positive and significant effect on taxpayer compliance. Financial conditions have a negative and significant effect on taxpayer compliance.

Financial conditions moderates the effect of satisfaction on service quality is negative and significant. Financial conditions moderating the effect of satisfaction on taxpayer compliance is negative and significant. Financial condition moderates the effect of awareness on taxpayer compliance is positive and significant.

\section{CONCLUSION AND SUGGESTION Conclusion}

The results showed that service quality, satisfaction and awareness partially had a positive and significant effect on taxpayer compliance. Financial conditions have a negative and significant effect on taxpayer compliance.

Financial conditions moderates the effect of satisfaction on service quality is negative and significant. Financial conditions moderating the effect of satisfaction on taxpayer compliance is negative and significant. Financial condition moderates the effect of awareness on taxpayer compliance is positive and significant.

\section{Suggestion}

Some suggestions for follow-up are as follows:

1. It is hoped that further researchers will further develop this research in terms of research respondents and other variables in order to provide comparisons. 
2. In terms of the KPP Pratama Deli Serdang process, it must improve complete facilities to make it easier for the public to pay taxes.

3. Deductions and administrative costs must be in accordance with those determined by the tax officials so that people are more obedient in paying their income tax $(\mathrm{PPh})$ and feel comfortable when transacting.

4. KPP Pratama Deli Serdang should not differentiate between groups in determining income tax so that the level of community compliance increases.

5. KPP Pratama Deli Serdang should often socialize with the public about being aware of and obediently paying taxes so that people better understand their obligations to pay taxes, that an increase in regions and even countries will develop and develop if the taxes set must be paid in accordance with the responsibilities given.

6. It is recommended that KPP Pratama Kisaran improve the quality of good service so that people can feel comfortable.

\section{Acknowledgement: None}

\section{Conflict of Interest: None}

\section{Source of Funding: None}

\section{REFERENCES}

1. Hamdani, Supirman. (2013). Pengaruh Kualitas Pelayanan Pajak, Kesadaran Wajib Pajak dan Pengetahuan Pajak Terhadap Kepatuhan Wajib Pajak (Survei Pada Wpop Yang Terdaftar Di Kpp Pratama Bandung Karees). Jurnal UNPAD.

2. Julianti, Murni. (2014). Analisis Faktorfaktor yang Mempengaruhi Kepatuhan Wajib Pajak Orang Pribadi untuk Membayar Pajak Dengan Kondisi Keuangan dan Preferensi Resiko Wajib Pajak Sebagai Variabel Moderating. Tesis UNDIP.
3. Kurniawan, Albert. (2010). Belajar Mudah SPSS Untuk Pemula. Yogyakarta: Mediakom.

4. Rangkuti. (2012). Manajemen Persedian Aplikasi Dibidang Bisnis Manajemen. Jakarta: PT Raja Grafindo Persada.

5. Sinulingga, Sukaria. (2014). Metode Pelitian. Medan: USU Press.

6. Syahputra, Lian Ade, Rika Kharlina Ekawati, \& Icha Fajriana. (2011). Pengaruh Kesadaran Wajib Pajak, Pengetahuan Pajak dan Kualitas Pelayanan terhadap Kepatuhan Wajib Pajak Reklame di Dinas Pendapatan Kota Palembang. Tesis UNRI.

7. Syahputra, Robert. (2015). Pengaruh Sanksi, Kesadaran Perpajakan dan Kualitas Pelayanan Wajib Pajak Terhadap Kepatuhan Wajib Pajak Bumi dan Bangunan (Studi Empiris Pada Wajib Pajak Kabupaten Pasaman). Tesis UNBRAW.

8. Utama, I Wayan Mustika. (2011). Pengaruh Kualitas Pelayanan, Sanksi Perpajakan dan Biaya Kepatuhan Terhadap Kepatuhan Wajib Pajak. Tesis UDAYANA.

9. Widodo, Joko. (2014). Good Governance: Telaah dari Dimensi: Akuntabilitas dan Kontrol Birokrasi pada Era Desentralisasi dan Otonomi Daerah. Surabaya: Insan Cedikia.

10. Yasa, I Putu Risky Perdana \& Jati, I Ketut. (2015). Kondisi Keuangan Wajib Pajak Pemoderasi Pengaruh Sanksi Perpajakan, Kesadaran Wajib Pajak pada Kepatuhan Wajib Pajak. Jurnal UDAYANA.

11. Yudi, Arista. (2011). Pengaruh Kualitas Pelayanan dan Kewajiban Moral Terhadap Kepatuhan Wajib Pajak dalam Membayar Pajak Kendaraan Bermotor pada Kantor Bersama Samsat Denpasar. Jurnal UDAYANA.

How to cite this article: Sinaga ES, Rini ES, Sembiring BKF. Effect of service quality, satisfaction and awareness on taxpayer compliance with financial conditions as moderating variables at the tax service office (KPP) Pratama Deli Serdang. International Journal of Research and Review. 2021; 8(7): 267-271. DOI: https://doi.org/10.52403/ijrr. 20210737 